\title{
Networks and cooperation for sustainable development The role of local authorities and clusters in regional development and economic growth
}

\author{
Anna Mempel-Śnieżyk ${ }^{1}, \mathrm{PhD}$
}

\begin{abstract}
An important role of modern economy is to create a well-functioning system of connections and supporting relations between local actors (entrepreneurs, business environment institutions, $\mathrm{R} \& \mathrm{D}$ area and local authorities).Present economy emphasizes various levels of cooperation:global, regional, national and local, at the same time indicating that local activity is essential for reaching the Millennium Development Goals. It should be underlined that they expire in 2015, and in the next year new goals will be proposed: Sustainable Development Goals.Bearing in mind the above, the aim of the article is to present the role of local authorities and network cooperation in achieving economic growth and sustainable developmentof the modern world. The paper presents new trends in regional policy undertaken by the EU: cooperation at the local level and how to identify regions' domains using cluster.

In order to achieve this aim, the author used the qualitative methods, which allowed to broaden the knowledge concerning the examined phenomenon, the literature study of available literature, reports in the area of knowledge systematization and definitions related to clusters, regional development and the significance of local authorities.
\end{abstract}

Key words:importance of local authorities, clusters, economic growth, sustainable development

\section{Introduction}

One of the activities recently undertaken by the European Union (See Derlukiewicz, 2013)aspires to achieve a widely understood development decreasing world poverty and reaching Millennium Development Goals. The goals besides world poverty and hunger reduction include development and strengthening the worldwide partnership in the scope of development.Recently, various cooperation levels are emphasized: global, regional, national and local, focusing on the fact that "local action is essential in order to reach the Millennium Development Goals." (European Commission, 2008). The Millennium Development Goals which expire in 2015 will be replaced by new Sustainable Development Goals, which fit within the Post-2015 Development Agenda.According to mentioned Agenda the new goals are something more than just coping with poverty, hunger, improvement in basic education or health. The new goals should result in economic, inclusive and sustainable growth e.g. higher living standardsby accelerating income growth and increasing employment (Bates-Eamer, Carin, Ha-Lee, Lim, Kapila, 2012). 
Since the year 2000 the world has changed and countries face new challenges in achieving sustainable development. They are conscious that they should act towards sustainable development and nowadays this is the key aim the future generation will face. Poland, like other EU members has committed to implement sustainable development policies by integrating activities in the economic, social and environmental areas for the benefit of future generations. The adopted strategy sets out a vision of Poland in 2015 as a country with a high level and quality of life and a strong and competitive economy capable of creating new jobs. Poland still has yet to undertake a new programme and activities to achieve the intended goals.

A continuation and improvement of activities started in the last decade can be help achieve new goals. "The world" is conscious of a constantly increasing role of innovations. Nowadays, the R\&D sector, innovative environment and the ability of economies to implement research results, seems more likely to be a guarantee of higher innovativeness of companies and regions.Furthermore, the knowledge, technological development and continuous innovation are key elements for ensuring the development and competitive advantage of particular economies. The ability to continually generate and adapt new technologies and new knowledge contributes to socio-economic development, influences the quality of life, develops information society, allows for improvement and new achievements in eco-economy. There are a lot of programmes and projects undertaken by international organizations, national or regional authorities in order to improve innovativeness and competitiveness of particular economies. "Sustainable improvements in human wellbeing is the ultimate purpose of all development effort. Achieving that purpose substantially depends on a foundation that binds together and gives balanced weight to economic progress, social equity, a healthy environment and democratic governance. These dimensions of development are too deeply intertwined to treat separately" (Independent Research Forum, 2013).

With the above in mind, the aim of this article is to determine the role of local authorities and network cooperation insustainable development of the modern world. To this end, the qualitative methods were applied in the article, which allowed to broaden the knowledge concerning the examined phenomena, the literature study of available works, reports on systematization of theknowledge and definitions related to local development and significance of local authorities and in relation to Poland.

\section{Local authorities}

Recently, there has been an increased interest in economic challenges that require an ambitious economic policy for the $21^{\text {st }}$ century. The EU has set out its vision for Europe's social market economy in the Europe 2020 strategy(European Commission, 2010a) which aims at confronting our structural weaknesses through progress in three mutually reinforcing priorities:

$\checkmark \quad$ smart growth, based on knowledge and innovation;

$\checkmark \quad$ sustainable growth, promoting a more resource efficient, greener and competitive

economy;

$\checkmark \quad$ inclusive growth, fostering a high employment economy delivering economic, social and territorial cohesion." (Guide to Research...,2012) 
The European Union perceives the possibility of reaching the above mentioned goalsby supporting cooperation in a broad sense at the local and regional level, between highly developed and the most poorly developed countries. Currently, the socio-economic development is observed locally all over the world, and it is difficult to imagine separate spatial units without the engagement of self-government authorities. The task of authorities is, therefore, to create high potential for innovation in the field of cultural, strong internal economic, social and institutional ties.

Hence, development and strengthening of the worldwide partnership is to be achieved by the supporting activity of local authorities, non-governmental institutions and local communities, and by spreading the idea of cooperation. For this purpose, the European Commission has undertaken a range of projects aimed at strengthening local authorities and other entities contributingto the development of particular countries, including the most poorly developed ones.

In order to expand world partnership the form of the cooperation must constantly develop. EU members have been conscious of that and promote supporting local and regional development with higher goals in mind. Most interactions and cooperation between elements of an innovative regional system occur at the regional level. Presently, particular territories as regionsare perceived as adequate for implementing a policy and programmes to implement innovations. Regional level and building regional systems are perceived as one of the best for improvement of economic innovativeness. Furthermore, the participants of this system play a very important role (enterprises, authorities, III sector, R\&D sector and other business support institutions). The promoted bottom - up approach is also led by businesses who opt to pursue a lot of potential strategies, radical new innovations, or modernise via adopting new technologies and processes. Therefore, the private sector is perceived as the driving force for implementing innovations but there are more than one participant in the process. Local governments also participate in creating conditions for focusing on innovativeness economic development. It can take the form of coordinating the activities of individual entities, problem and conflict solving, initiating economic projects beneficial in terms of harmonious development, initiating cooperation between enterprises and business environment and creating favourable conditions for new entrepreneurs (MempelŚnieżyk, 2013).

Activities of local authorities can be analysed in terms of small and mediumenterprises (SMEs) and the crucial role of SMEs in the regional development and economic growth. The SMEs sector is seen today as one of the most important pillars of the economy. SMEs consist of $c a .99 \%$ of all businesses within the European Union andSMEs' contribution to the economic sustainability and wealth is considered relevant. SMEs stimulate countries' economic growth by activating innovation process and arecrucial to improvingeconomic competitiveness. Moreover, they offer an opportunity of selfemployment and thereforegenerate new jobs and are highly dynamic in risk-taking, upgrade industrial structure and streamline resource allocation. The desired situation would be the smooth functioning of this sector, skillful overcoming the obstacles standing in the way of their development and creating conditions conducive to their development.

On the Polish example it can be seen thatthe role of local authorities in socio-economic development has been continually changing and their engagement is still required. The scope and engagement of these authorities are the focus of long-lasting debates. In 
Poland the SMEsector is the effect of transformation of the country. In Poland this sector did not develop until the transformation period (in the 90s). The appearance of this sector resulted in creating new jobs and prevented the deepening of unemployment which was the effect of liquidation and restructuring of state enterprises. It is also assumed that development and activity of SMSs contributed to the sustainable growth of our country in recent years. The development of the SME sector was especially successful taking into account the external conditions of the period, such as lack of stable activities on the part of state regulatory structures, difficulties in obtaining external funding, unequal conditions of competition favouring public and large entities. Years of centrally planned economy and the resultingdifficulties for the operation of small and medium enterprises did not turn out to be a barrier or a problem to be solved, but the driving force for their formation and development. It wouldn't be possible without changes in legal regulations, forming a support system andengagement of local authorities. The time scale for such significant changes was obviously long-term and has been continuing until now.

The relevant literature provides a number of divisions and classifications of the ways in which local authorities can affect the development of local entrepreneurship in the community. It can be e.g. the creation and development of technical infrastructure, or support for institutional, organizational and economic incentives for entrepreneurs. It should be noted that setting up a business and the choice of location depends largely on the enterprise and its capital, intangible assets and its aspirations. The role of local authorities is significant and may create favourable organizational and infrastructural conditions.

Another aspect connected with the activities of local authorities is creating infrastructural facilities as a major investment in supporting the development of economic activity at the local level. Forming favourable conditions is extremely important for both local authorities as well as the local community. This is related to the local market which is the base for SMEs in terms of supply of labour resources, materials, intermediate goods, financial resources, use of advisory services or promotion, which, in turn, contributes to the socio-economic activation of the territory (Markowski, Stawasz, 2001, p. 115). That is why, the preparation of an investment offer by local authorities both to new potential investors and already existing ones, seems to be extremely important-they influence the situation of SMEs and create a good business climate. To do that, local authorities can form a system of local businesses, allow for utilizing local natural resources,local human resources or create location availability via spatial planning. Local authorities, due to their closeness to local entrepreneurship can be helpful in creating cooperation networks, or take the role of a network broker. Networks of connections between SMEs are perceived as beneficial for this group of enterprises and furthermore for socio-economic and sustainable development.

\section{Network cooperation for economic growth}

3.1 Network cooperation background

The references literature provides numerous diverse descriptions of the phenomenon of concentration of enterprises. They are interrelated by a network of various cooperation and competition relations and connections with other sectors of the economy (e.g. concentrated around universities, other R\&D institutions, with support and connections between local authorities). This phenomenon related to mutual 
cooperation between theabove mentioned entities is more frequently called jointly as territorial structures or just clusters. The roots of the cluster concept refer to the idea ofan industrial district and perfect competition model ofthe $19^{\text {th }}$ century economist Alfred Marshall (1920). The concept of cluster is based on the theory of production specialization anddraws on the works following researchers among others: Perroux (1950), who underlined the meaning of key industriesand growth pole theory influencing spillover effects to other branches of economy, Dahmen(1950) who developed theconcept of development blocks (Dahmen, 1988, pp 3-14) which contribute to swarms of innovations and result in the creation of new activitiesand branches, or later approaches based on industrial districts so called "new industrial district", Bagnasco (1977), who coined the notion of Third Italy, and others Becattini (Becattini, 1979), Capecchi (1992). Furtheremore, Sengenberger and Pyke(1992), whose research was related to how companies grouped within a district are organized, created organization of entities as a system of relations between the companies and the environment organizations. In the literature a large variety of network structures can be found, but the most popular one was coined by Porter (1988), who introduced a model called Porter's diamond of competitiveness (Porter, 1990). He is the precursor of the cluster term in the economy and it is his works that have had the greatest influence on the form of the concept of cluster.

\subsection{The concept of cluster}

The cluster approach was widespread in 90' and in the last decade is regained its importance. Clusters are still perceived as offering policymakers the opportunity to better streamline different policies towards the objective of stimulating growth through innovation.Clusters can provide a fertile combination of entrepreneurial dynamism and contribute to building a knowledge-based economy, in line with the Europe 2020 strategy (European Commission, 2010b)the cluster concept has become an important element of the EU economic policy because it employs priorities of the Europe 2020 Strategy.Clusters play an important role in creating connections between economic entities, i.e. enterprises and the R\&D sector, whose relations are a key element used in modern models of innovation processes. Clusters are able to influence the acceleration of development processes. Apart from well-known benefits, which result from clusters and translate into improvement of competitiveness of the participating enterprises, should be underlined general development of the region what follows: the increased standard of living, increased income, greater entrepreneurship of the residents and activity of local authorities. ${ }^{1}$

From the point of view of this paper it is very importantto emphasise the role of clusters for SMEs located in it. The researcher, who have investigated benefits and effects for enterprises located in clusters, have underlined in their works that this companies grow faster than average, are more innovative, have the possibility for "productively source for inputs, access information, technology and institutions; and coordinate with other firms both horizontally and vertically" (Kuah, 2002 ,p.213). Clusters directly contribute to investments in infrastructure, stimulating innovative infrastructure, increasing the significance of the regional R\&D sector, promoting the idea of information society and increasing the availability of specialised business support services.Creating a supportive

\footnotetext{
${ }^{1}$ Benefit klastar
} 
environment for dynamic development of entrepreneurship and innovation is a complex challenge which requires special skills and knowledge. In order to enhance the importance of diverse skills and knowledge and to describe the dynamic of relations between enterprises, the R\&D sector and authorities the „triple helix" model has been proposed (Etzkowitz, Leydesdorff, 1995). The process occurring between the abovementioned entities is understood as a learning process which develops through mutual cooperation aiming to build innovative systems.

The references literature providesvarious typologies of clusters e.g. according to the Department of Trade and Industry (DTI, 2001), OECD (2001), Meyer-Stamer (MeyerStamer, 1999). As mentioned above, the cluster approach is not new, but clusters are still considered structureswhich contribute to innovativeness of companies, regions and furthermore whole economies. Additionally, in the 90' the notion of innovation networks was also coined. This notion result from adoptingtoongoing changes, to newsurroundings and conditions (increasing role of ICTs in all aspects of life), by developing new technologies(Knell, 2011, p.5).Innovative networks enable dissemination of knowledge and ideas,adopt and develop good innovative practices, share knowledge on newly emerging technologies and standards of innovative technologies, exploit innovation synergies and explore new technologies (Knell, 2011, p. 5). Innovation networks by using $R \& D$ potential give a chance for improvement in another sphere of human life. Through spreadinginnovative technologies, good practices etc. innovation networkscreate benefits for both members as well as entities from outside the network(See Ahuja, 2000).

\section{Cooperation for sustainable development}

Lately, a great interesting achieving economic growth, with particular focus on its sustainable aspect, has forced particular governments, global institutions and companies to enhance activities leading to sustainable development. Sustainable development is defined asdevelopment that meets "the needs of the present without compromising the ability of future generations to meet their own needs" (Brundtland Commission,1987).Furthermore, presently the EU is undertaking a number of projects aiming atenhancing innovativeness e.g. Innovation Union - theflagship initiative - as part of the Europe 2020 strategy, focused on investing in research, innovation and entrepreneurship (Innovation Union..., 2013). The Digital Agenda for Europe initiativefocuses to deliver sustainable economic growth and social benefits from ICT and is also part of Europe 2020 (Digital Agenda..., 2013).

Connections between network structures as clusters and sustainable development are not so precise. More frequently, descriptions related to sustainable development andSMEs alone can be found in the scientific literature. The groundbreaking approach referring to the rise of sustainability within the business world was presented by Savitz and Weber.In The Triple Bottom Line the authors explained the connections between increase of financial success accompanied by social and environmental achievements. The authors undertake the real problems that companies face and the innovative solutions that can result from sustainability(Savitz, Weber, 2006). The linkages between business and sustainable development refer to different types of innovations (sustainable innovation or ecoinnovation) that have a reduced negative impact on the environment.(see more: Klewitz, Hansen, 2012, p.9) 
Presently,SMEs contribute to ca. 64\% of the industrial pollution in Europe (ECEI,2010). This sector finds it more difficult to deal with environmental legislation compared to large companies, which are able to find financial resources, undertake and promote their "environmental" activities. The EU members face the problem of transforming environmental challenges into business opportunities for SMEs. To this end, cost reduction, environmental impact and increased energy efficiency are promoted. Less than a half of SMEs (40-45\%) are companies with high impact on the environment. They are more likely to invest in environmental solutions because of business opportunities (cost reduction or in accordance with environmental legislation). The second group of SMEs (55-60\%) rather prefer low-cost solutions: simple clean technologies, recycling of water or waste, or just energy-efficient light bulbs, waste segregation. However, economic and environmental results of these activities are also limited.(ECEI, 2010). In view of the above the introduced environmental management systems (EMS) should be better suited for different types of enterprises. It seems to be adequate only for medium or large enterprises which can afford such a certificate and have higher environmental impact, but for micro and small companies it is too costly, too complicated and they are rather not interested. The possibilities of improving environmental performance should be supported by easier access to certification of environmentally friendly products and sector-specific events focused on eco-industry opportunities, training for green skills, simple guidelines, support for marketing campaigns for eco-products, services etc. The chance and solution to reaching the above listed changes can be cooperation and linkages between SMEs in the form of cluster.

Recently, networks and cooperation has become an important factor in regional sustainable development, which force authorities to drive the policy allowing for more efficient use of resources, greener development and more competitive economy.Achieving regional sustainable development is more possible using the power of cooperation between economic entities and according to the common saying "act separately but together". "Clusters promote specific collaborations and networks, in which common sustainability goals can be achieved more easily”(Knauseder, 2013, p. 9).

According to The European Cluster Memorandum Europe faces innovation challenges.Clusters can be powerful catalysts in the process of improving innovation performance andseekto sustain high and rising standards of living (European Commission, 2007).The regional policy related to clusters has to concentrate on areas of existing or potential regional advantages(European Commission, 2008), investment in knowledge infrastructure, science parks and business incubators (European Union, 2010)and boosting the network relations between regional authorities, enterprises and universities. As a result of synergic actions linkageshave appeared, leading towards sustainability and innovativeness of economies. (see more: Slovell,2008) The importance of clusters, as an element of economic development, is recognised by the European Union and EUmembers are guided to formally identify clusters and to recognise SMEs' relevance to economic sustainability and wealth(European Commission 2008b).

Lately, the cluster approach has been used in linkages with the concept of smart specialization, a territorial development model in order to increase the efficiency and effectiveness of economic systems contributing to sustainable development simultaneously (Castillo, Paton, Saez, Desarrollo, 2013, p. 1). Smartspecializations strategies(3S) approach appeared because of difficulties in reaching the US economic innovativeness by the EU, and because of the need to invest limited public funds more 
efficiently in regional economic development. This concept was also proposed as an answer to searching new, more sustainable growth concepts. This approach is important in new regional policy to the point thataccording to the European Commission's proposals on cohesion policy for the period 2014-2020, smart specialisation will be a precondition for the use of funds from the European Regional Development Fund in 2014-2020. Smart specialisation is an alternative to a policy that promotes investment across several areas and sectors irrespective of a region's industrial structure and knowledge capacity (concerning human capital, universities, research organisations etc.).According to Ketels (Ketels, 2013) clusters can be used to identify valuable assets of the region. Clusters located in particular regions help to create synergies between businesses, universities and research, reinforce linkages using existing strengths and opportunities. Clusters contribute to long-term development of sustainable competitive advantages by region. Clustersfavour and facilitate identification of the regions' potential and domains."Clusters strengthen regional identity and thus encourage the participation of stakeholders in the process of sustainable regional development"(Knauseder, 2013, p. $9)$.

\section{Conclusion}

The conducted research, concerning contribution of networks and cooperation between economic entities for sustainable development, point to the continuous needfor changes in the EU and policy of particular countries. To this end, new or revised approaches and concepts have been proposed. Though a new proposition, they base on those rooted in the regional policy e.g. supporting clusters as popular economic development strategy.

To achieve the article objectiveand present the role of local authorities and network cooperation in achieving economic growth and sustainable development of the modern world the paper has considered new trends in regional policy undertaken by the EU. The first part outline the global vision of present and future goals and priorities for achieving sustainable development in the world. This part briefly introduces the importance of local authorities in the present socio-economic development. To sum up can be underline that local authorities are crucial for development because they are closest to the people and are most familiar with their needs. Moreover,undertaking local actions is vital for achieving sustainable human development (European Commission, 2008). Furthermore, the author underlines the role of local authorities in supporting local development and creating high potential for innovation by creating partnership and linkages between economic entities. This part also presents the small and medium enterprises as a powerful sector for creating cooperation networks for economic growth and innovativeness of the economy. The second part of the paper focuses on the relationship between enterprises and benefits of network concepts for both networks participants as well as regions they are located in. In particular it is related to concept of cluster. Finally, the last part analyses the elements regarding networks and cooperation between economic entities and sustainable development. The last partpresent the cluster approach not as a new concept but a still important thanks to its contribution to innovativeness of companies, regions and furthermore whole economies. The clusters via endogenous development, benefits for region andfor cluster-members exceed 
obvious advantages and foster creating added value according to the theorem which says that the whole is more than the sum of its parts.

To sum up, it can be added that creating networks positively influences sustainable development. By state- and non-state actors participating in networks their common goals can be reached. Local authorities, while performing their duties in accordance withnational and EU guidelines, focus in their activities on the needs of their local entities and take into account specific conditions. The support and benefits for theSME sector resulting from participation in a network increase the awareness and responsibility for acting in accordance with sustainable development. Due tothe possibility of realizing join actions they seem to find it easier to achieve higher goals.

\section{References}

Ahuja, G. (2000). Collaboration networks, structural holes, and innovation: A longitudinal study. Administrative Science Quarterly, 45, ABI/INFORM Global, pp 425-455.

Brundtland Commission. (1987). Brundtland Report. Oslo - Norway: United Nations.

Bagnasco, A.(1977). Tre Italie. La problematica territoriale dello sviluppo italiano.Il Mulino, Bologna.

Bates-Eamer, N., Carin, B., Ha-Lee, M., Lim, W., Kapila, M. (2012). Post-2015 Development Agenda: goals, targets and indicators. Special Report. The Centre for International Governance Innovation and the Korea Development Institute. Online available: http://www.cigionline.org/sites/default/files/MDG_Post_2015v3.pdf.

Becattini, G.(1979). Dal settore industriale al distretto industriale. Alcune considerazioni sull'unità di indagine dell'economia industriale, Rivista di Economia e Politica Industriale, n. 1.

Capecchi, V. (1992). A history of flexible specialisation and industrial districts In Emilia - Romagna. In: Industrial districts and inter firm co-operation in Italy. Ed. F. Pyke, G. Becattini, W. Sengerberger, Geneva:International Institute for Labor Studies, pp. 20-21.

Castillo, J., Paton, J., Saez, A., Desarrollo, I. (2013). Smart Specialisation And Clusters: The Basque Country Case Online available: http://www.reunionesdeestudiosregionales.org/Oviedo2013/htdocs/pdf/p880.pdf

Dahmén, E. (1950).Svensk industriell företagarverksambet. Kausalanalys av den industriella utvecklingen 1919-1939. Del I-II. PhD diss Industriens utredningsinstitut. Stockholm.

Dahmén, E. (1988). Development blocks in industrial economics. The Scandinavian Economic History Review. Vol 36 no 1, pp 3-14.

Derlukiewicz, N. (2013), Prospects for innovation development in the European Union according to the new Europe 2020 strategy.Research Papers of Wroclaw University of Economics no. 324, Wroclaw, Wroclaw University of Economics,pp. 27-36.

Digital Agenda for Europe. A Europe 2020 Initiative, (2013).Online available: http://ec.europa.eu/information society/digital-agenda/.

DTI,(2001). Bussiness clusters in the UK - a first assessment, London:Minister of Science.

Etzkowitz H., Leydesdorff, L. (1995). The Triple Helix - University - Industry - Government Relations: A Laboratory for Knowledge Based Economic Development, EASST Review 14, pp. 14-19.

European Commision,(2007). The European Cluster Memorandum, Stockholm, Online available:http://www.proinno.net/upload/documents/european_cluster_memorandum_final1.pdf.

European Commision,(2008a). Changing the world... locally - 25 success stories of development cooperation at local level. Online available:

http://gobernanzalocal.files.wordpress.com/2012/01/success-stories en fin.pdf.

European Commission, SEC (2008b). 2637: 33. http:/ / ec.europa.eu/enterprise/policies/innovation/files/clusters-working-document-sec-20082635 en.pdf

European Commission (2010a). COM (2010) 2020 Europe 2020. A European strategy for smart, sustainable and inclusive growth, Brussels, 3.3.2010. Online available: http:/ / ec.europa.eu/eu2020/pdf/COMPLET\%20EN\%20BARROSO $\% 20 \% 20 \% 20007 \% 20$ \%20Europe $\% 202020 \% 20-\% 20$ EN $\% 20$ version.pdf. 
European Commission Enterprise and Industry (Eds.) (ECEI), (2010). SMEs and the Environment in the European Union. Denmark: Teknologisk Institut. Online available: http://ec.europa.eu/enterprise/policies/sme/business-environment/files/main_report_en.pdf.

European Commission, (2010b).Commission Staff Working Document accompanying the Commission Communication on Regional Policy contributing to smart growth in Europe 2020, http://eurlex.europa.eu/LexUriServ/LexUriServ.do?uri=CELEX:52010SC1183:EN:NOT.

Guide to Research and Innovation Strategies for Smart Specialisation (RIS 3), (2012). Online available: http://s3platform.jrc.ec.europa.eu/en/c/document library/get file?uuid=e50397e3-f2b1-40868608-7b86e69e8553.

Independent Research Forum (IRF 2015). Post-2015: framing a new approach to sustainable development, Policy paper, 2013, Online available: http://sustainabledevelopment.un.org/content/documents/874irf2015.pdf

Innovation Union. A Europe 2020 Initiative, (2013).Online available: http://ec.europa.eu/research/innovation-union/index en.cfm.

Ketels, Ch. (2013).Clusters and Public Policy: Recent Learnings, Current Challenges, - Lisbon, online available: http://www.observatorio.pt/download.php?id=909.

Klewitz, J., Hansen, E.G. (2012). Eco-innovation in SMEs An in-depth case analysis of transforming SMEs through effective partnerships, Lueneburg, Online available:

$<$ http://www2.leuphana.de/umanagement/csm/content/nama/downloads/download_publikati onen/Klewitz,\%20Hansen_Ecoinnovation $\% 20$ in $\% 20$ SMEs.pdf.

Knauseder,J. (2009).Business clusters as drivers of sustainable regional development? An analysis of cluster potentials for delivering sustainable development in regions- with a case study of the Mexican automotive cluster Saltillo - Ramos Arizpe, Online available: https://emnet.univie.ac.at/uploads/media/Knauseder_01.pdf.

Knell, M.(2011).Global Networks of innovators: A synthesis of research issues, Maastricht Online available: http://final.dime-eu.org/files/Knell_C3.pdf.

Kuah A.T.H. (2002).Cluster Theory and the Small Business Journal of Research in Marketing and Entrepreneurship: Volume 4, Issue 3, pp.206-228.

Markowski T., Stawasz D. (ed.) (2001).Ekonomiczne $i$ środowiskowe aspekty zarzqdzania rozpojem miast $i$ regionón.Łódź, Publisher of Universityof Lodz, Łódź.

Marshall, A. (1920). Principles of Economics. An Introductory volume, $8^{\text {th }}$ ed., The MacMillan Press, London.

Mempel-Śnieżyk, A. (2013). Local actors and local development. The case of Poland, Research Papers of Wroclaw University of Economics no. 283, Wroclaw, Wroclaw University of Economics pp. 9 -16.

Meyer-Stamer, J.(1999). Strategien lokaler/regionaler Entwicklung: Cluster, Standortpolitik und systemische Wettbewerbfähigkeit, Institut für Entwicklung und Frieden, Duisburg:Universität Duisburg.

OECD,(2001). Innovative Clusters. Paris.

Perroux, F. (1950). Economic Spaces: Theory and application, Quarterly Journal of Economics, No 64.

Porter, M.E. (1990).The Competitive Advantage of Nations, MacMillan, London,

Porter, M.E. (1998). Clusters and the new Economics of Competitions, Harvard Business Review, NovemberDecember: 77-90.

Pyke F., Sengerberger W. (1992). Industrial districts and local economic regeneration: Research and policy issues. In: Industrial districts and local economic regeneration. Red. F. Pyke, W. Sengerberger., Geneva:International Institute for Labor Studies.

Savitz, A.W., Weber, K. (2006). The Triple Bottom Line: How Today's Best-Run Companies are Achieving Economic, Social and Environmental Success - And How You Can Too. San Fransisco, USA: Jossey-Bass A Wiley Imprint.

Solvell, O. (2008).Clusters - Balancing Evolutionary and Constructive Forces, Stockholm:Ivory Tower Publishing 